\title{
Method to Calculate the Electricity Generated by a Photovoltaic Cell, Based on Its Mathematical Model Simulations in MATLAB
}

\author{
Carlos Morcillo-Herrera, ${ }^{1}$ Fernando Hernández-Sánchez, ${ }^{1}$ and Manuel Flota-Bañuelos ${ }^{2}$ \\ ${ }^{1}$ Scientific Research Center of Yucatan, A.C., 43 Street, No. 130, Chuburná Hidalgo, 97200 Mérida, YUC, Mexico \\ ${ }^{2}$ Department of Engineering, Autonomous University of Yucatán, Nonpolluting Industries Avenue, No. 150, Cordemex, \\ 97310 Mérida, YUC, Mexico \\ Correspondence should be addressed to Fernando Hernández-Sánchez; fhs@cicy.mx
}

Received 18 May 2015; Revised 7 September 2015; Accepted 8 September 2015

Academic Editor: Xudong Zhao

Copyright ( 2015 Carlos Morcillo-Herrera et al. This is an open access article distributed under the Creative Commons Attribution License, which permits unrestricted use, distribution, and reproduction in any medium, provided the original work is properly cited.

This paper presents a practical method for calculating the electrical energy generated by a PV panel (kWhr) through MATLAB simulations based on the mathematical model of the cell, which obtains the "Mean Maximum Power Point" (MMPP) in the characteristic $V$ - $P$ curve, in response to evaluating historical climate data at specific location. This five-step method calculates through MMPP per day, per month, or per year, the power yield by unit area, then electrical energy generated by PV panel, and its real conversion efficiency. To validate the method, it was applied to Sewage Treatment Plant for a Group of Drinking Water and Sewerage of Yucatan (JAPAY), México, testing $250 \mathrm{Wp}$ photovoltaic panels of five different manufacturers. As a result, the performance, the real conversion efficiency, and the electricity generated by five different PV panels in evaluation were obtained and show the best technical-economic option to develop the PV generation project.

\section{Introduction}

According to the World Energy Outlook 2014, the global demand for electricity continues to rise at a high rate [1]. This incremental demand is supplied by fossil fuels by $70 \%$, while the remaining $24 \%$ is supplied by nuclear energy and hydropower, and only $6 \%$ is supplied by renewable energy. Renewable energy sources have the characteristics of generating clean energy available in nature, contributing to supplying energy demanded of users, reducing the fossil fuels exhaustion, and mitigating the emission of greenhouse gases [2].

Renewable energy with the largest power generation capacity installed is wind power; however, solar energy is growing at a faster rate than any other form of renewable energy. Solar energy is available everywhere in the world; it is considered inexhaustible and has a higher annual generation potential than the annual electricity generation worldwide. The solar energy potential is harnessed by thermal and photovoltaic systems to generate electricity either on a large scale as a solar farm or on small scale as an autonomous or grid connected photovoltaic system (SFV) [3]. Today, the SFV begins to penetrate the world market as an opportunity for electrical energy microgeneration, thanks to the opening in regulations, rules, and policies worldwide, increasing the conversion efficiency of the new cells and the cost reduction per kilowatt installed [4]. However photovoltaic technology still has significant challenges; one of them is its perception as a source of energy with a prolonged and unreliable return of investment. This is caused by uncertainty in the amount of electricity generation, due to the daily variations of climatic factors, at the locality where the SFV is installed. A determining factor for investment in photovoltaic generation projects is to have the most realistic estimate of electricity generated by SFV from solar energy available in the locality; therefore, a practical method to calculate this energy is required.

The first proposed works in the literature focus the efforts to calculate theoretically the energy potential radiated per square meter $\left(\mathrm{kW} / \mathrm{m}^{2}\right)$ for a locality, due to the high cost 


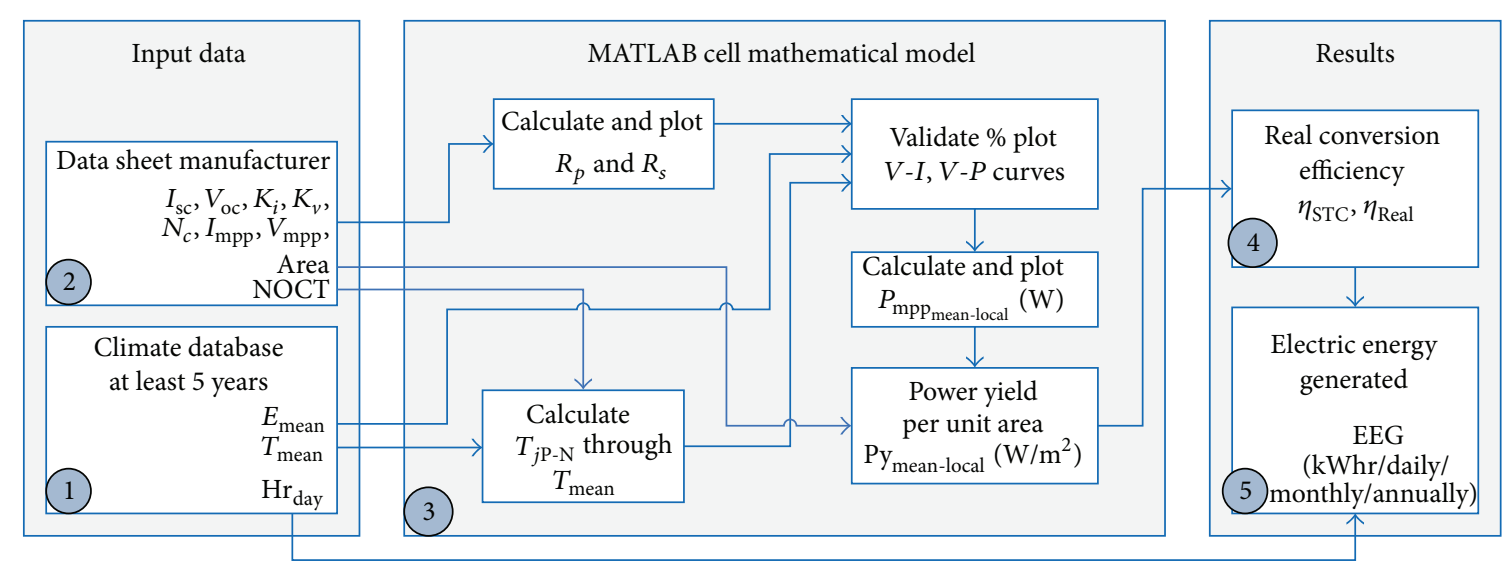

Figure 1: Proposed method flowchart.

associated with instruments measuring solar radiation. The proposed methods are based on solar radiation data, as C. Hotel's model that is based on direct radiation [5], LiuJordan's model that is based on diffuse radiation [6], and other theoretical models that are based on both radiations [7]. From the earlier works, a second-step model is presented in the literature to estimate energy potential in available areas such as roofs and facades in urban buildings or houses, with the target of estimating incident energy radiated $\left(\mathrm{kWhr} / \mathrm{m}^{2}\right)$, for planning SFV applications. These proposals are based on digital or mathematical surface models (DSM) [8,9], climatic data simulations [10], geographic information systems (GIS) [11-13], and photovoltaic geographical information system (PVGIS) [14]. All previous methods estimate the energy potential but not the electricity generation by the panel PV. Recently a model was presented for estimating the cell power considering ambient conditions [15] and their dependence on irradiance and temperature [16]; however, this methodology does not consider the number of sunlight hours and the intrinsic cells characteristic. These previous models are based on the GIS, using the available annual average radiation data and efficiency of PV panel to estimate the generation.

Therefore, the methods stated above estimate the potential for solar radiant energy for a specific location, but they do not estimate the real electric energy generation of PV panel. In practice, the difference between the potential energy radiated regarding the electric power generated by a PV panel is significant; this is due to the panels only generating their maximum power peak, under conditions of $1000 \mathrm{~W} / \mathrm{m}^{2}$ at a cell temperature of $25^{\circ} \mathrm{C}$, known as standard test conditions (STC). It is known that there are locations around the world where STC is not reached and therefore the cell never reaches the maximum power point specified by the manufacturer.

Then, the electricity generated by PV cell is a function of the solar incident radiation $(E)$; the cell junction temperature $\left(T_{J P-N}\right)$; the sunlight exposure hours $\left(\mathrm{Hr}_{\text {day }}\right)$; the cell conversion efficiency $(\eta)$; and its maximum power point (MPP) [17].

The last two factors depend on the intrinsic characteristics of the cells and will be reflected in the $V-I$ and $V$ - $P$ characteristic curves, so there are differences between different manufacturers.
The aim of this paper is to provide a method using MATLAB to calculate the electrical energy generation of a cell based on its mathematical model and a reliable historical climate database.

\section{Method Development}

The proposed method is based on a photovoltaic cell mathematical model and requires, as input, manufacturer cell data sheet and a climate database. As output, the efficiency and electrical energy generated by a PV panel are obtained.

The flowchart (Figure 1) shows the sequence of the fivestep method, which was implemented in the MATLAB simulation software.

Step 1 (historical climate database). PV panels are sensitive to radiation and temperature variations. When the $\mathrm{P}-\mathrm{N}$ junction temperature of the cell is increased, the output voltage is reduced. Likewise when the incident radiation in the cell reduces, its current output reduces too. The reductions of voltage, current, or both are reflected directly in an output power reduction and therefore reduce the energy conversion efficiency [18]. Given the influence of these parameters on the electricity generation of PV panels, it is necessary to have a reliable climate database of the location, at least five years of records to have a tendency. The parameters required by database are as follows: temperature daily mean $\left(T_{\text {mean }}\right)$, radiation daily mean $\left(E_{\text {mean }}\right)$, and daylight hours daily mean $\left(\mathrm{Hr}_{\mathrm{day}}\right)$.

Globally, there are several databases available that can be used such as the Center for Atmospheric Sciences NASA Langley Research Data (LaRC), which provide 22 years of historical data from any quadrant of the globe defined by longitude and latitude [19], and the database of the European Solar Radiation Atlas (ESRA) [20]. Most countries have an official climate database; in Mexico the Water National Commission (CONAGUA) provides a database with records for each state over the last 50 years [21]. Several governmental or educational institutions maintain climate records such as the Advanced Research Center (CINVESTAV) in Merida, Yucatan, Mexico [22]. 

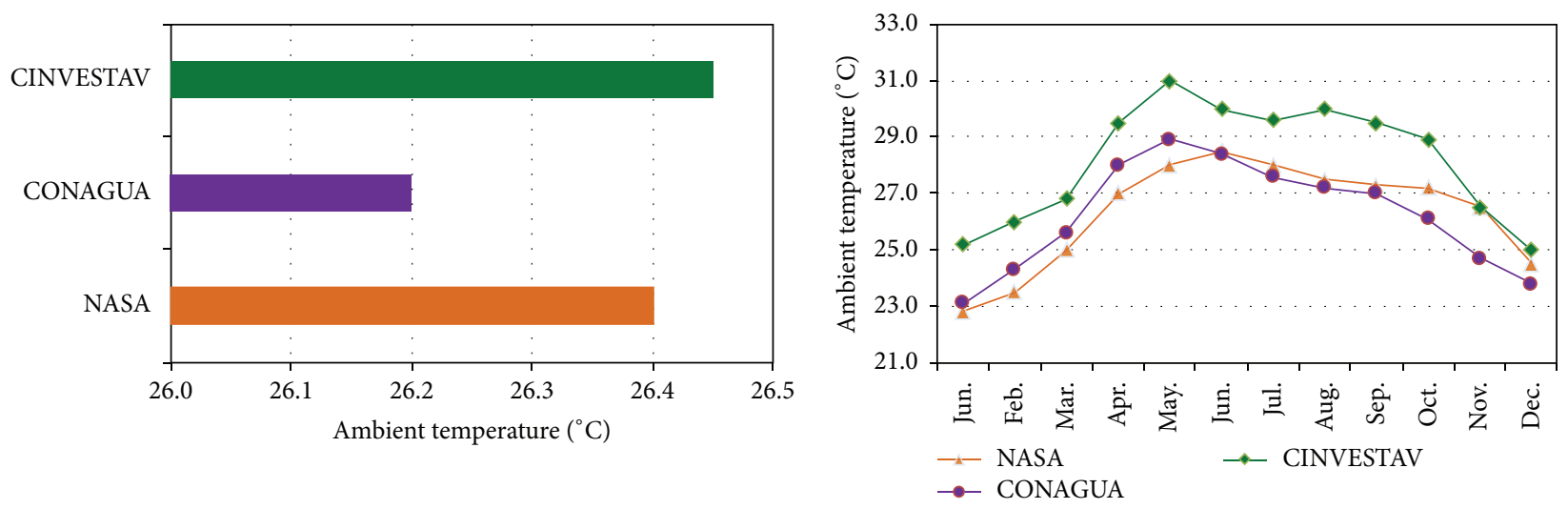

FIGURE 2: Temperature annual and monthly daily mean.
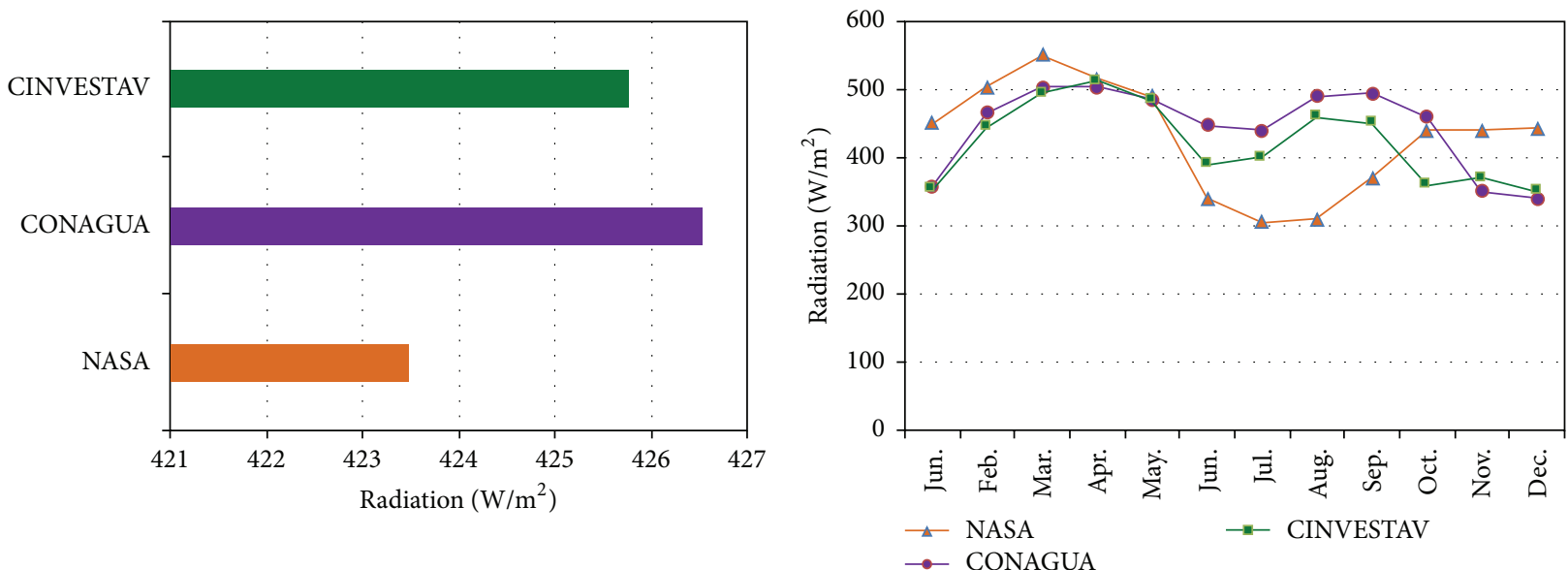

FIgURE 3: Radiation annual and monthly daily mean.

While a database for a location is more specific, the calculation of the method has major approximation to reality; therefore a local database is recommended.

In this case the proposed method was applied to a PV project in a Sewage Treatment Plant for a Group of Drinking Water and Sewerage of Yucatan (JAPAY) located at Merida, same place as CINVESTAV.

Temperature Annual Daily Mean. Using CINVESTAV climate database to validate the proposed method and using the NASA and CONAGUA database as reference, Figure 2 shows the temperature annual and monthly mean $\left(T_{\text {mean }}\right)$, averaging at least five years for Merida city.

CINVESTAV database indicates that $T_{\text {mean }}$ per year is $26.45^{\circ} \mathrm{C}$, NASA database indicates $26.4^{\circ} \mathrm{C}$, and CONAGUA database indicates $26.2^{\circ} \mathrm{C}$. These records validate the CINVESTAV database which will be used in this method. $T_{\text {mean }}$ value for Merida is $26.45^{\circ} \mathrm{C}$.

Radiation Annual Daily Mean. Using the same procedure, the radiation daily mean $\left(E_{\text {mean }}\right)$ of at least 5 years was obtained.
In Figure 3 the database records of annual and monthly radiation are presented. According to the CINVESTAV database, in Merida city, $E_{\text {mean }}$ is $425.78 \mathrm{~W} / \mathrm{m}^{2}$.

Daylight Hours Annual Daily Mean. Applying the same procedure, the number of hours of daylight $\left(\mathrm{Hr}_{\text {day }}\right)$ is shown in Figure 4, for an annual and monthly daily mean of at least five years. The CINVESTAV database indicates that the number of hours with daylight for Merida is $12.17 \mathrm{hr}$.

Step 2 (data cell manufacturer). The intrinsic characteristic of photovoltaic cells is that other factors determine the performance and efficiency conversion of radiant energy into electrical energy.

Therefore, it is important to identify in the manufacturer data sheet the following parameters: short-circuit current $\left(I_{\mathrm{sc}}\right)$, open circuit voltage $\left(V_{\mathrm{oc}}\right)$, the temperature coefficient of $I_{\mathrm{sc}}\left(K_{i}\right)$, the temperature coefficient of $V_{\mathrm{oc}}\left(K_{v}\right)$, the total number of cells connected in the panel $\left(N_{c}\right)$, the current at the maximum power point $\left(I_{\mathrm{mpp}}\right)$, the voltage at the maximum power point $\left(V_{\mathrm{mpp}}\right)$, the nominal operating cell temperature (NOCT), and the panel area $\left(\mathrm{m}^{2}\right)$. In order to implement 

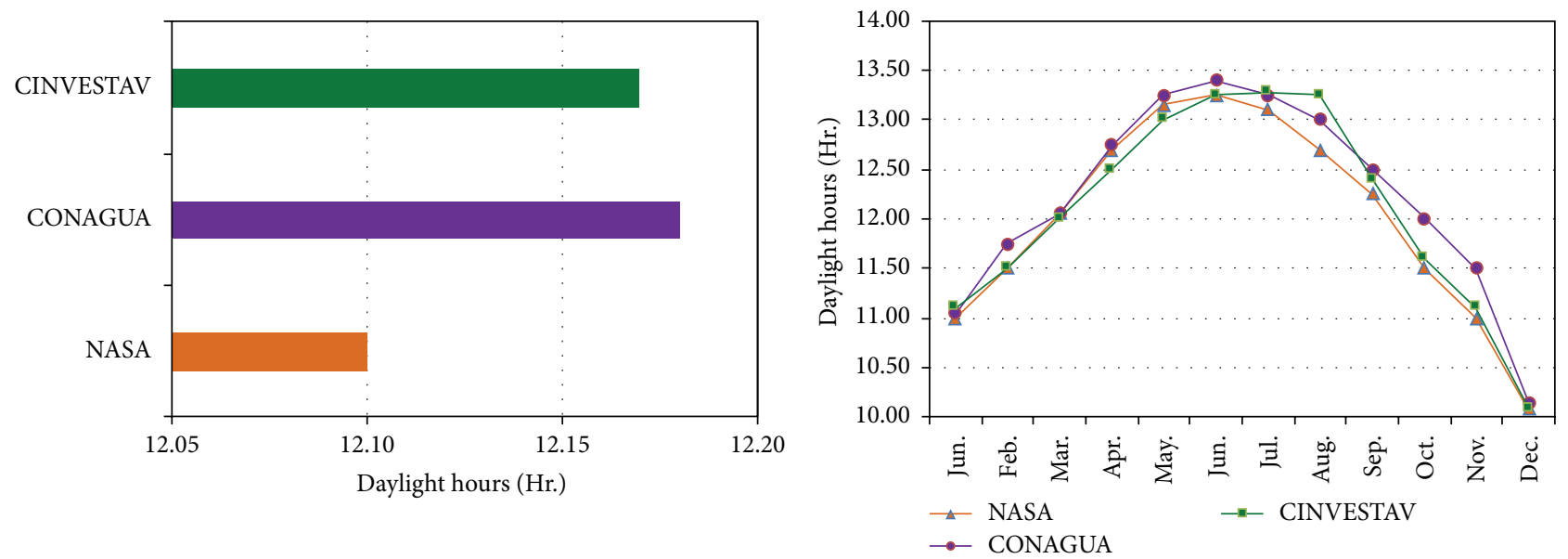

FIGURE 4: Daylight hours annual and monthly daily mean.

TABLE 1: Data sheet parameters of $250 \mathrm{Wp}$ PV panel.

\begin{tabular}{lcccccccc}
\hline NOCT & $V_{\text {mpp }}$ & $I_{\text {mpp }}$ & $V_{\text {oc }}$ & $I_{\text {sc }}$ & $K_{i}$ & $K_{v}$ & $N_{c}$ & Area \\
\hline 45 & 30.12 & 8.3 & 37.85 & 8.65 & 0.005 & -0.17 & 60 & 1.62
\end{tabular}

the proposed method, a $250 \mathrm{Wp}$ polycrystalline photovoltaic panel S60PC, Solartec brand, is used as an example for calculation [23]. Table 1 shows the values of the parameters of S60PC PV panel at STC.

Step 3 (cell mathematical model in MATLAB). In order to determine the maximum electrical power point $\left(P_{\mathrm{mpp}}\right)$ that a $\mathrm{PV}$ panel generates with a specific junction temperature value $\left(T_{J P-N}\right)$ and radiation $\left(E_{\text {mean }}\right)$ a mathematical model of the photovoltaic cell is necessary to approximate the nonlinear behavior, through its $V-I$ and $V$ - $P$ curves.

The simplest mathematical model reported includes one diode parallel to a current source [24, 25], where the current source represents $E_{\text {mean }}$ and the diode represents the P-N cell junction. An improved version adds the series resistance $\left(R_{s}\right)$ effects at the output circuit, to enhance model accuracy, but it exhibited deficiencies with high values of junction temperature $[26,27]$.

Later it was suggested to add the effect of a parallel resistance $\left(R_{p}\right)$ with diode and current source to improve the behavior of the model $[28,29]$. Recently Ishaque et al. proposed a mathematical model that adds a second diode in parallel, increasing accuracy without losing the simplicity, modeling with better yield to partial shading, and will be applied to monocrystalline and polycrystalline PV panels with low errors [30].

The last two diodes' mathematical model, represented by the equivalent circuit of the PV cell shown in Figure 5, will be used to derive equations that will lead to the mathematical model which is the base of this step.

The values of the series and parallel resistance $\left(R_{s}\right.$ and $R_{p}$ ), appearing in the equivalent circuit of the cell, are not

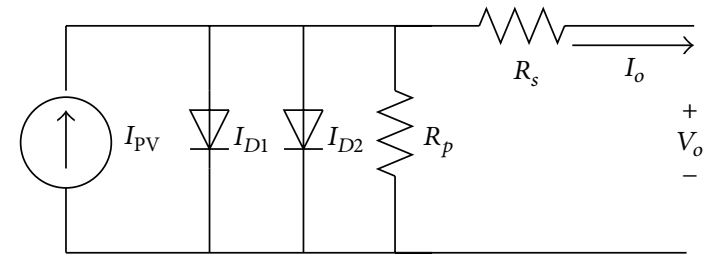

FIgure 5: Two diodes' PV cell equivalent circuit.

available in the manufacturer data sheet. To obtain these values, clearing $R_{p}$ and $R_{s}$ from the mathematical equations was required. Applying Norton's theorem for nodes analysis, the following equation is derived:

$$
I_{o}=I_{\mathrm{PV}}-I_{D 1}-I_{D 2}-I_{R_{p}}
$$

where $I_{o}$ is the output current of PV cell; $I_{\mathrm{PV}}$ is the current generated by the incidence of light; $I_{D 1}$ and $I_{D 2}$ are currents of diode 1 and diode 2, respectively; and $I_{R_{p}}$ is the current of parallel resistance.

Replacing $I_{D 1}$ and $I_{D 2}$ by the diode characteristic equation and replacing $I_{R_{p}}$ in terms of output voltage $\left(V_{o}\right)$ and output current $\left(I_{o}\right),(1)$ can be rewritten as

$$
\begin{aligned}
I_{o}= & I_{\mathrm{PV}}-I_{\mathrm{SAT} 1}\left[\exp \frac{q\left(V_{o}+I_{o} R_{s}\right)}{N_{c} K T_{j \mathrm{P}-\mathrm{N}}}\right] \\
& -I_{\mathrm{SAT} 2}\left[\exp \frac{q\left(V_{o}+I_{o} R_{s}\right)}{N_{c} K T_{j \mathrm{P}-\mathrm{N}}}\right]-I_{R_{p}}, \\
I_{o}= & I_{\mathrm{PV}}-\left[I_{\mathrm{SAT} 1}+I_{\mathrm{SAT} 2}\right]\left[\exp \frac{q\left(V_{o}+I_{o} R_{s}\right)}{N_{c} K T_{j \mathrm{P}-\mathrm{N}}}\right] \\
& -\frac{V_{o}+I_{o} R_{s}}{R_{p}},
\end{aligned}
$$

where $I_{\mathrm{SAT} 1}$ and $I_{\mathrm{SAT} 2}$ are the reverse saturation currents of diode 1 and diode 2, respectively; $K$ is the Boltzmann 
constant; $q$ is the electron charge; $N_{c}$ is the number of cells; and $T_{j \mathrm{P}-\mathrm{N}}$ is the junction temperature of cell.
To obtain $R_{p}$ value in terms of $R_{s}$ in the $P_{\mathrm{mpp}}$, it is necessary to replace $V_{o}$ with $V_{\mathrm{mpp}}$ and $I_{o}$ with $I_{\mathrm{mpp}}$, and this was obtained after cleaning and replacing:

$$
R_{p}=\frac{V_{\mathrm{mpp}}+I_{\mathrm{mpp}} R_{s}}{I_{\mathrm{PV}}-\left[I_{\mathrm{SAT} 1}+I_{\mathrm{SAT} 2}\right]\left[\exp \left(\left(q\left(V_{\mathrm{mpp}}+I_{\mathrm{mpp}} R_{s}\right)\right) / N_{c} K T_{j \mathrm{P}-\mathrm{N}}\right)-1\right]-I_{\mathrm{mpp}}} .
$$

Calculation of $R_{p}$ and $R_{s}$. From (3), $R_{p}$ is function of $R_{s}$, and then, for a finite and positive $R_{s}$ value, $R_{p}$ is obtained through iterations of $R_{s}$ so that it approximates $P_{\mathrm{mpp}}$. Applying the equations in MATLAB simulation for photovoltaic panel subject to test, a series or family of curves $V-I$ and $V-P$ is obtained, which permitted finding $R_{s}$ and $R_{p}$ value, closest to $P_{\mathrm{mpp}}$. Several techniques have been demonstrated with simulations by Shongwe and Hanif [31], Xiao et al. [32], Ishaque and Salam [33], and Márquez et al. [34] to model one or two diodes.

Figure 6 shows the result in MATLAB of the characteristic curves $V-I$ and $V-P$, which through iterations obtained the value of $R_{s}=0.37 \Omega$ and $R_{p}=400 \Omega$ for the $250 \mathrm{Wp}$ panel S60PC.

Calculation of Junction P-N Temperature. From the annual daily average of temperature $\left(T_{\text {mean }}\right)$ that was obtained from climate database, it was necessary to calculate the value of $T_{\text {JP-N }}$ that causes the effect on output voltage. Definitely there is a relationship between the ambient temperature and the junction temperature cell. However this relationship is not direct or linear.

In practice, it is a complex task to measure the cell junction temperature and other variables involved such as solar radiation, wind speed, the spectral distribution of the irradiation, the absorption capacity and heat dissipation, and the intrinsic construction material, as was reported by Lasnier and Gang-Ang [35]. In the literature, there are several studies of methods and procedures for determining the coefficient of temperature junction cell, as were presented by King et al. [36], which uses the short current and open circuit voltage of the PV cell. A practice equation for estimating the junction temperature cell is presented by García and Balenzategui [37], through calculations based on the nominal operating cell temperature (NOCT) in compliance with international standards EN-61646, EN-61215, and E1036M applicable to polycrystalline, monocrystalline, and thin film cells.

The value for NOCT of a cell is available on the manufacturer data sheet. The procedure for determining the junction temperature from NOCT is based on the fact that the difference between ambient temperature and the junction temperature is associated but is independent, and it also has a directly proportional relationship to the radiation for values between 400 and $1000 \mathrm{~W} / \mathrm{m}^{2}$. This allows for determining the junction temperature based on the following equation:

$$
T_{\text {JP-N }}=T_{\text {mean }}+(\text { NOCT }-20) \frac{E_{\text {mean }}}{800} .
$$

Replacing the value of $T_{\text {mean }}=26.45^{\circ} \mathrm{C}, E_{\text {mean }}=425.78 \mathrm{~W} /$ $\mathrm{m}^{2}$, and NOCT $=45$, the value of $T_{J P-N}=39.75^{\circ} \mathrm{C}$ is obtained for $250 \mathrm{Wp}$ PV panel.

Validating V-I and V-P Characteristic Curves. Starting from (2) that describes the mathematical model of the photovoltaic cell in terms of the output voltage and output current, it is required to rewrite $I_{\mathrm{PV}}, I_{\mathrm{SAT} 1}$, and $I_{\mathrm{SAT} 2}$ in terms of $E_{\text {mean }}$ and $T_{\text {JP-N }}$ :

$$
\begin{aligned}
& I_{\mathrm{PV}}=I_{\mathrm{sc}}+K_{i} *\left(T_{J \mathrm{P}-\mathrm{N}}-25\right) \frac{E_{\mathrm{mean}}}{1000}, \\
& I_{\mathrm{SAT} 1}=I_{\mathrm{SAT} 2} \\
& =\frac{I_{\mathrm{sc}}+K_{i} *\left(T_{J \mathrm{P}-\mathrm{N}}-25\right)}{\exp \left[\left(q\left(V_{\mathrm{oc}}+\left[K_{v} *\left(T_{J \mathrm{P}-\mathrm{N}}-25\right)\right]\right)\right) /\left(N_{c} * K * T_{J P-\mathrm{N}}\right)\right]-1},
\end{aligned}
$$

where the values of $K_{i}, K_{v}$, and $N_{c}$ are available in the manufacturer data sheet as described in Step 2.

Using MATLAB Simulink language, the proposed method was implemented and integrated in a scheme that is shown in Figure 7. The values of data sheet parameter PV panel and $T_{\text {mean }}$ and $E_{\text {mean }}$ from climate database were described. After the value declarations, there are two "interpreted MATLAB function blocks" that represent MATLAB programs to calculate $T_{J \mathrm{P}-\mathrm{N}}$ from $T_{\text {ambient }}$ value and calculate $R_{s}$ and $R_{p}$ values. The center of the figure is a mask which was the main equation (2) developed (Figure 8). In the mask, the value of mean maximum power point (MMPP) and the power yield per unit area was obtained by evaluating and simulating all historic parameters. In the end, there is a third "interpreted MATLAB function block" to calculate the aim of this method and the efficiency and the electricity energy generated by the PV panel.

To prove the mathematical model, the characteristic curve $V$ - $P$ with different values of $T_{J P-N}$ and $E$ was plotted, from the values defined for the STC. To validate the performance cell simulated in MATLAB, the $V-P$ characteristic curve provided by the manufacturer was compared with the curve plotted in MATLAB. The maximum power point $\left(P_{\mathrm{mpp}}\right)$ had to match with the PV panel power peak defined by the manufacturer. The characteristic curves families obtained for the $250 \mathrm{Wp}$ PV panel are shown in Figure 9, denoting that $P_{\mathrm{mpp}}$ is $250 \mathrm{~W}$.

Mean Maximum Power Point for Locality. Evaluating and simulating the historic climate data of $T_{J P-N}$ and $E_{\text {mean }}$, in the same $V$ - $P$ curve, plotted the result of evaluating the cell mathematical model for a specific PV panel and location. As a result, the Mean Maximum Power Point, now called MMPP, 

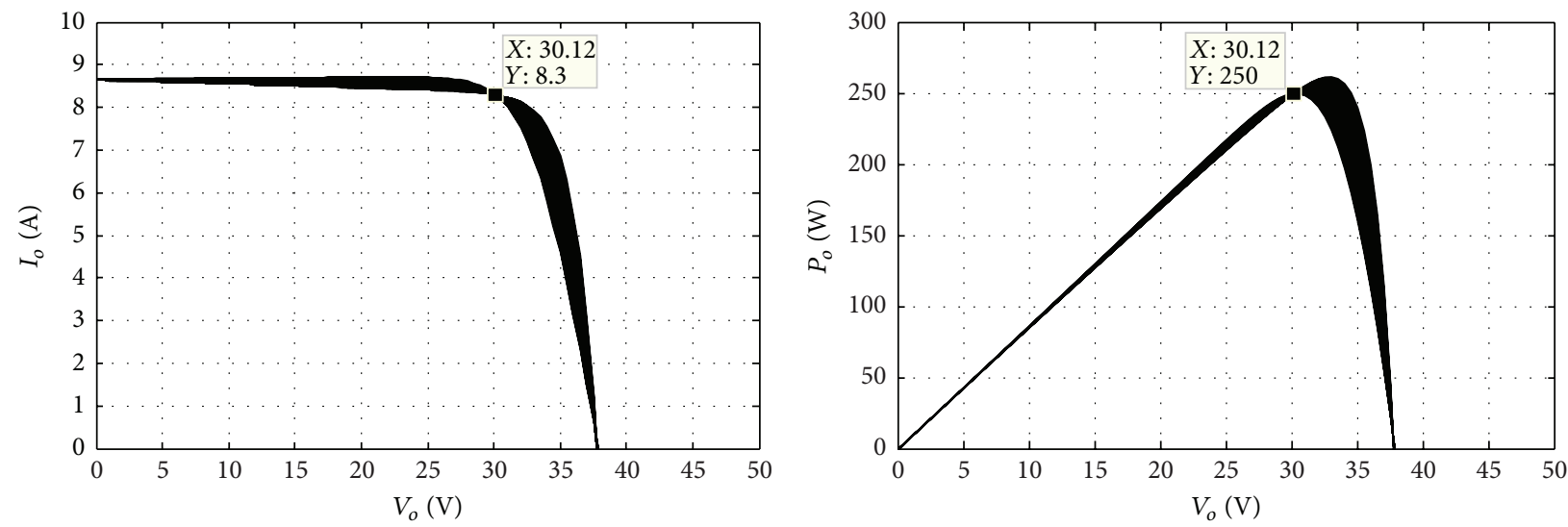

FIgURE 6: MATLAB iteration result to calculate $R_{s}$ and $R_{p}$.

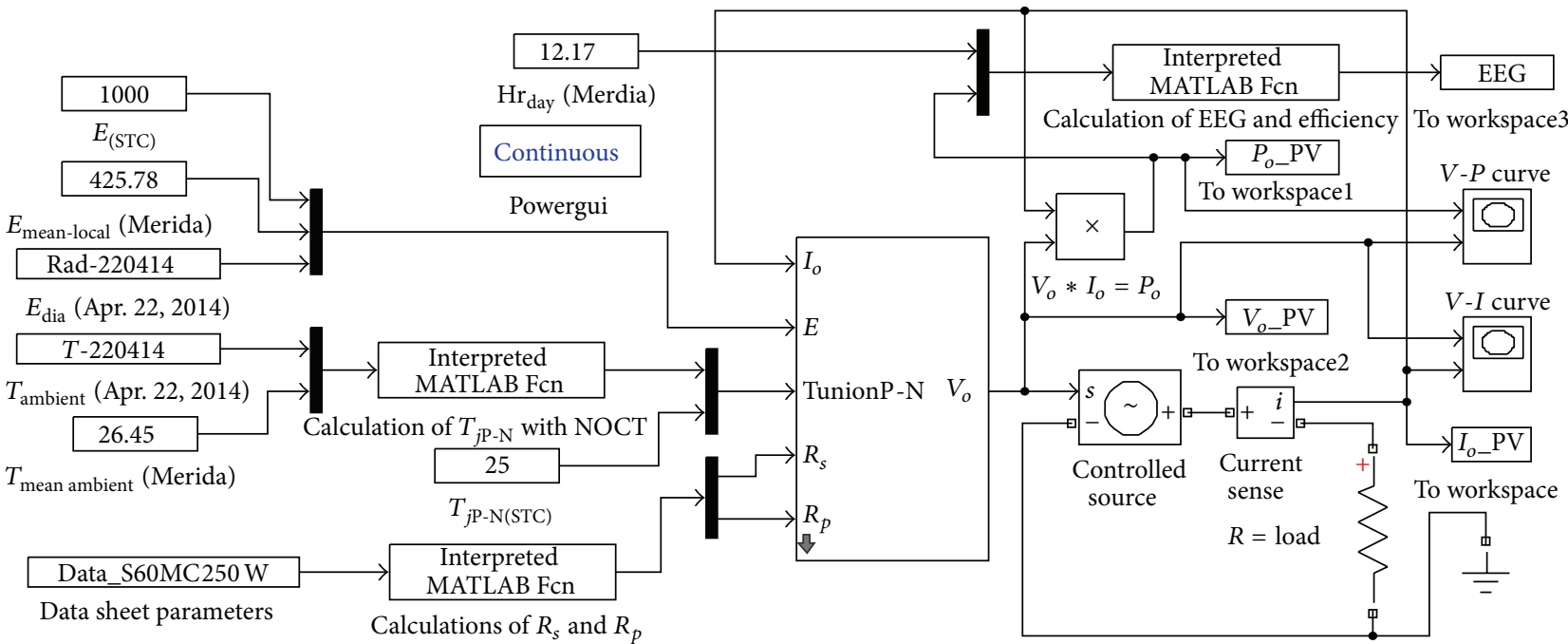

FIGURE 7: Implementation of proposed mathematical method in MATLAB Simulink.

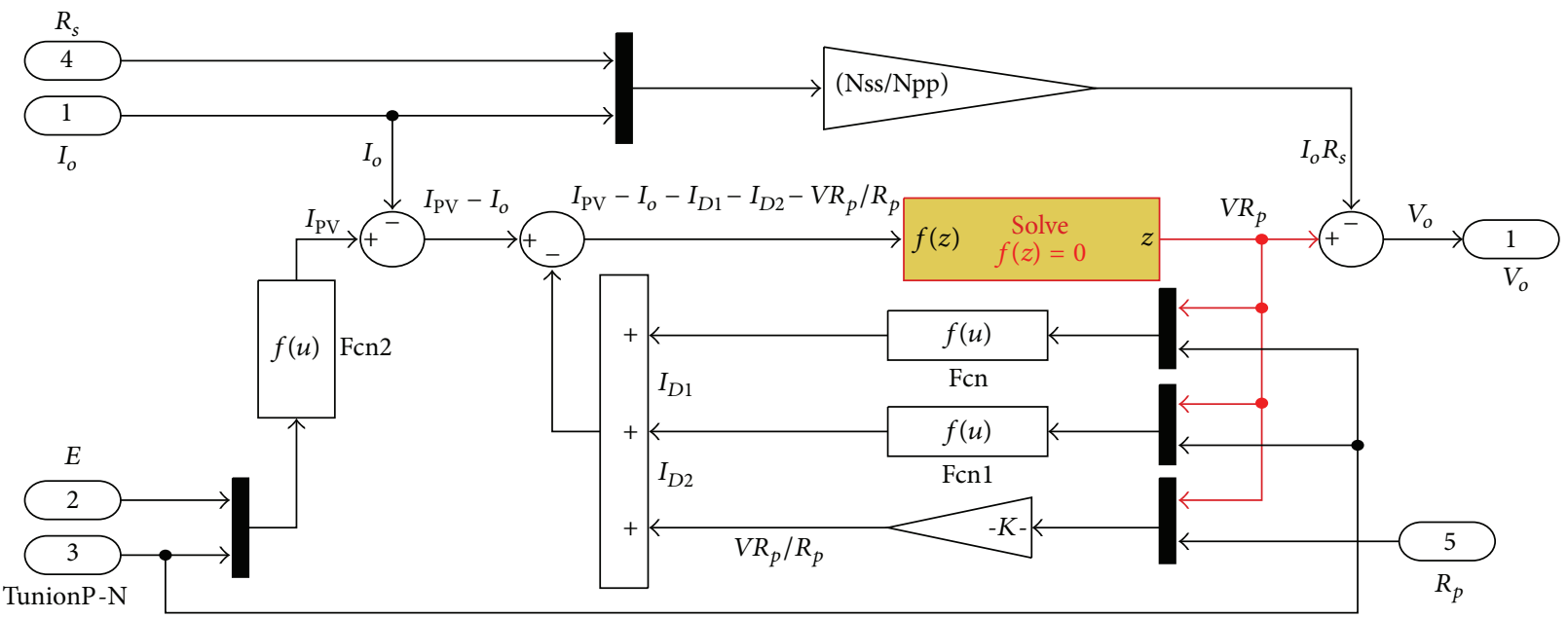

FIgURE 8: Cell mathematical model inside of MATLAB Simulink mask. 

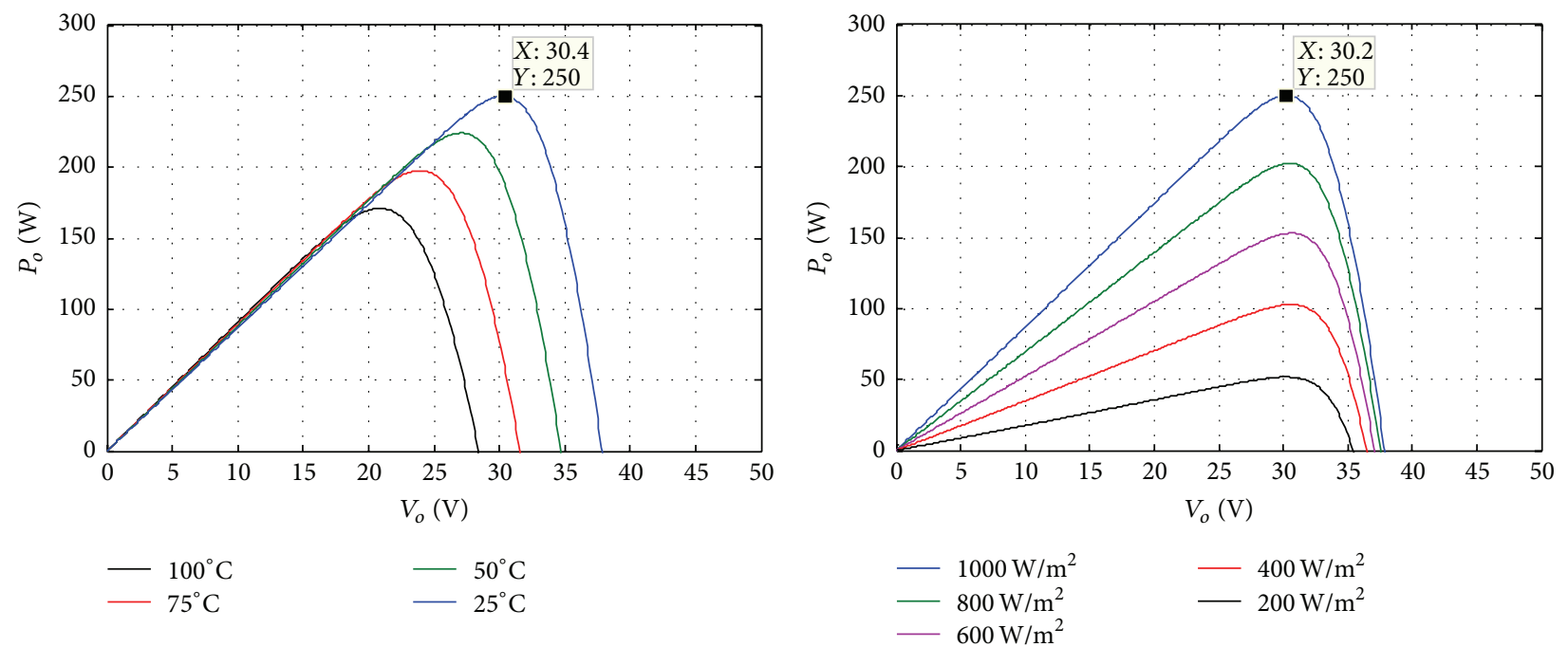

FIgURE 9: $V$-P curves evaluating values of $E_{\text {mean }}$ and $T_{J P-N}$ respect STC values.

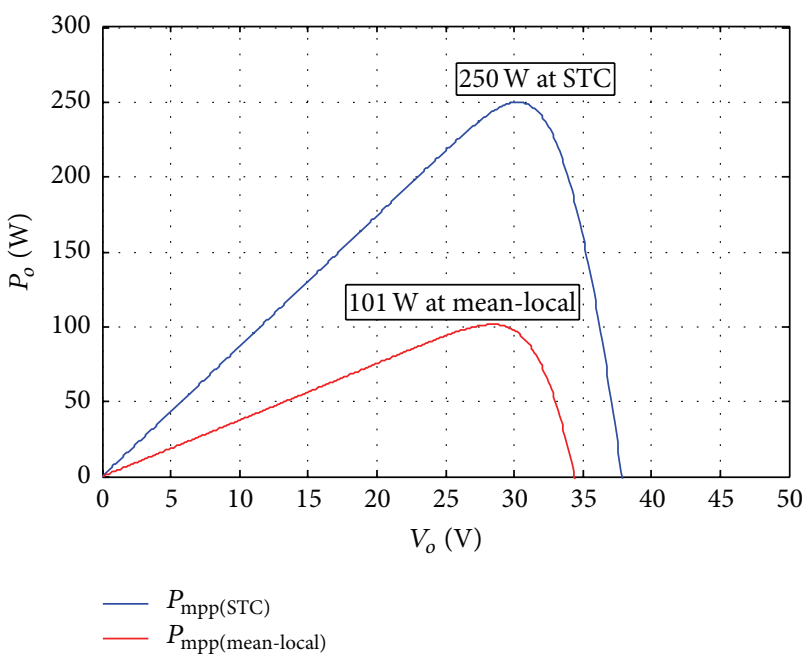

Figure 10: $V$ - $P$ curves result for $P_{\mathrm{mpp}(\mathrm{STC})}$ versus MMPP.

corresponds to the annual daily average of power for the last five years in Mérida city. Figure 10 shows the significant difference between $P_{\text {mpp }}$ displayed under STC, compared to MMPP at Mérida according to its historical weather.

The simulation result shows that, depending on the historical values of the temperature and radiation of a locality, the difference between $P_{\mathrm{mpp}(\text { STC) }}$ and MMPP should be more or less significant. For Merida city the result between both is $P_{\mathrm{mpp}(\mathrm{STC})}=250 \mathrm{~W}$ respect $\mathrm{MMPP}=101 \mathrm{~W}$.

Using the same method implemented in MATLAB Simulink, Figure 10 shows the results for a full day (Apr. 22, 2014) in Merida using the different values along the day of temperature and radiation.

Figure 11 demonstrates the behavior and variation of $P_{\text {mpp }}$ throughout the day. In the morning $P_{\text {mpp }}$ increased, in the middle of the day it reached its maximum, and in the afternoon it decreased its value. In fact, for this particular day

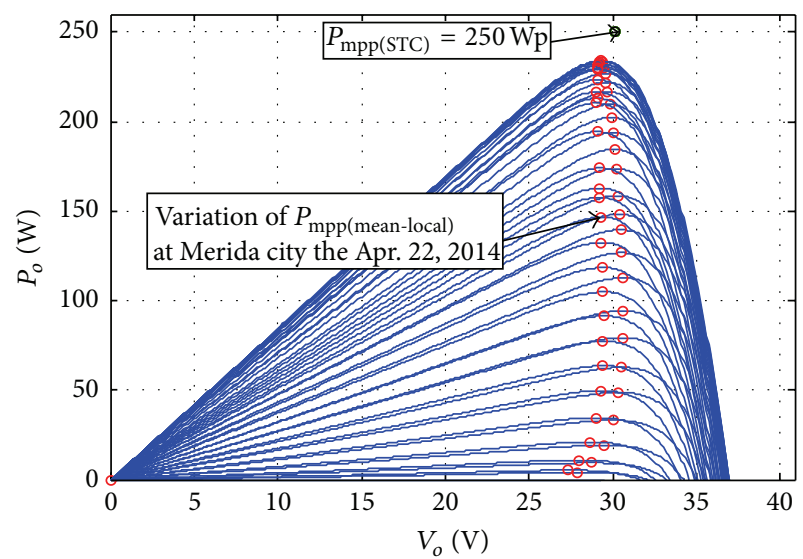

FIgURE 11: Simulation of $P_{\mathrm{mpp}}$ at Merida for all of one day.

and location, $P_{\mathrm{mpp}}$ did not reach the value of $P_{\mathrm{mpp}(\mathrm{STC})}$. This is the relevance to work with MMPP.

Power Yield per Unit Area. An important parameter in the planning electrical generation projects with photovoltaic energy is to know the PV panel power yield (Py) per unit area $\left(\mathrm{W} / \mathrm{m}^{2}\right)$. This data allows quantifying the area required for the SFV installation.

The Py can be calculated under two conditions: for real values corresponding to a locality, as described by (6), and for the values in STC conditions, as described by (7). $P_{\mathrm{mpp}(\mathrm{STC})}$ is the power peak provided for manufacturer data sheet:

$$
\begin{aligned}
\mathrm{Py}_{\text {local }} & =\frac{\mathrm{MMPP}}{\text { Area }_{\mathrm{PV}}}, \\
\mathrm{Py}_{\mathrm{STC}} & =\frac{P_{\mathrm{mpp}(\mathrm{STC})}}{\text { Area }_{\mathrm{PV}}} .
\end{aligned}
$$


Applying (6) and (7), the result for Merida and the $250 \mathrm{Wp}$ $\mathrm{PV}$ panel selected is $\mathrm{Py} \mathrm{STC}_{\mathrm{ST}}=154.32 \mathrm{~W} / \mathrm{m}^{2}$ whereas $P \mathrm{y}_{\text {local }}=$ $62.65 \mathrm{~W} / \mathrm{m}^{2}$.

There is a loss of yield greater than $60 \%$. So this fall should be attenuated or enhanced depending on the panel under test and the locality. A PV panel with high Py requires lower area than any other one with low Py. Therefore dimensioning the area with values at STC is not the most appropriate, because the MMPP varies from one locality to another, but this value is almost lower than $P_{\mathrm{mpp}(\mathrm{STC})}$.

Step 4 (real conversion efficiency). The real conversion efficiency $\left(\eta_{\text {real }}\right)$ indicates the rate between the power yield at locality and the annual daily mean radiation $\left(E_{\text {mean }}\right)$ per unit area in the same location. Substituting the values previously obtained of local power yield for the panel $250 \mathrm{Wp}$ at Merida city $\eta_{\text {real }}=14.71 \%$,

$$
\eta_{\text {real }}=\frac{P y_{\text {local }}}{E_{\text {mean }}}
$$

The manufacturer conversion efficiency $\left(\eta_{\text {STC }}\right)$ described in the data sheet was obtained through (9), comparing the power yield in contrast to the incident radiation at standard condition test. $\mathrm{Py}_{\mathrm{STC}}$ was obtained in (7), and $E_{\mathrm{STC}}$ was defined as $1000 \mathrm{~W} / \mathrm{m}^{2}$. The efficiency at STC is $\eta_{\text {STC }}=$ $15.43 \%$ :

$$
\eta_{\mathrm{STC}}=\frac{\mathrm{Py}_{\mathrm{STC}}}{E_{\mathrm{STC}}} .
$$

The difference between the real efficiency and standard efficiency indicates that even though it is the same panel, out of standard values, the efficiency always drops.

Step 5 (electric energy generated by a PV panel). The last step is to know the electric energy generated (EEG) by the PV panel. It can be obtained in two ways: by multiplying the instantaneous value of $P_{\mathrm{mpp}}$ for the duration of each sample and after adding all energy obtained or using MMPP and multiplying by daylight hours annual daily mean. The result was the same, so this paper uses the latter way to obtain EEG. EEG by PV panel in Merida can be calculated by the next equation:

$$
\mathrm{EEG}=\mathrm{MMPP} * \mathrm{Hr}_{\text {day }} .
$$

Applying the equation above the electricity generated was obtained for annual daily mean for each $250 \mathrm{Wp}$ PV panel S60MC at Mérida as a result of evaluating in MATLAB, historical climate data in the mathematical model of the photovoltaic cell. $\mathrm{EEG}=1.22 \mathrm{kWhr} /$ day.

\section{Results}

The proposed method was applied to a project for the Sewage Treatment Plant for Group of Drinking Water and Sewerage of Yucatan (JAPAY), México, testing $250 \mathrm{Wp}$ PV panels of five different manufacturers, to generate $95 \%$ of electric power
TABLE 2: $250 \mathrm{Wp}$ PV panel of different manufacturers.

\begin{tabular}{lcccc}
\hline Jinshi & Solartec & LDK & Canadian & Kewell \\
\hline NBJ-250W & S60MC250 & LDK250D2 & VirtusII250 & KWP-250W \\
$250 \mathrm{Wp}$ & $250 \mathrm{Wp}$ & $250 \mathrm{Wp}$ & $250 \mathrm{Wp}$ & $250 \mathrm{Wp}$ \\
\hline
\end{tabular}

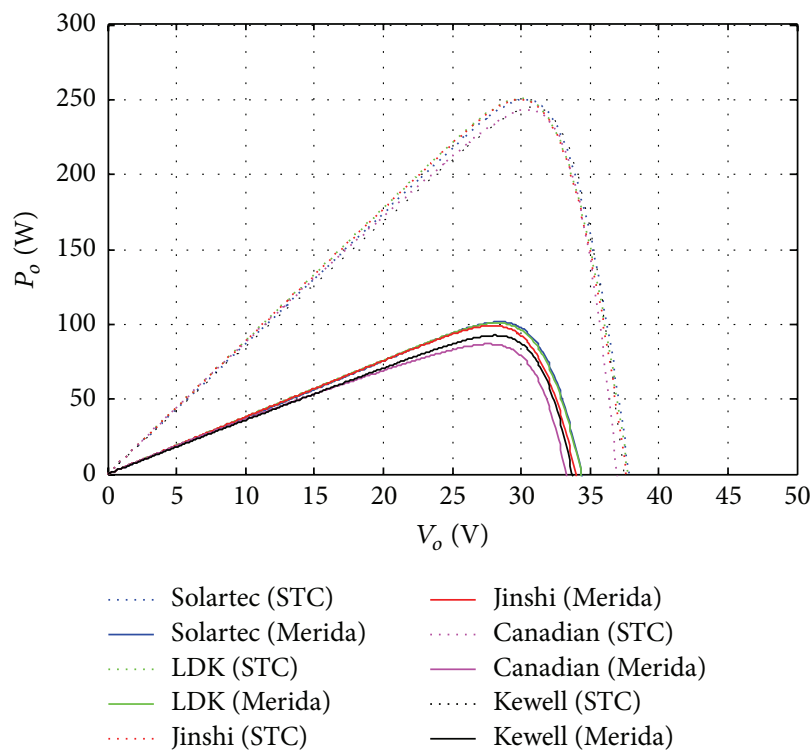

FIgURE 12: Simulation result of $P_{\operatorname{mpp}(\text { STC) }}$ versus MMPP in Merida for the 5 PV panels.

consumption daily average. Table 2 show the PV panel subject test.

The aim of using the proposed method in this project is to determine the electricity generated for each PV panel tested, likewise, to evaluate and select the best efficiency option, to reduce the cost of investment, and to lower the installation area, providing greater certainty and reliability for investment return.

Applying the three first steps of proposed method the results are presented in Table 3 for five PV panels tested.

To continue with the step there, the simulation results are evaluating simultaneously the 5 different PV panels to visualize and validate in the same graph the results of $P_{\text {mpp(STC) }}$ regarding MMPP. The resulting $V$ - $P$ curves are shown in Figure 12.

Table 4 shows the result of applying Step 4 to obtain the power yield and the real conversion efficiency, evaluating at STC and for Merida city for the same 5 PV panels.

Table 4 indicates that there are differences between the MMPP generated under Merida climatic conditions regarding $P_{\mathrm{mpp}(\mathrm{STC})}$, and therefore the power yield and the efficiency present differences. Some PV panels have greater efficiency than others.

Finally, applying Step 5, Table 5 presents the results of the electrical energy generated (EEG) at Merida, for each $250 \mathrm{Wp}$ PV panel evaluated in MATLAB simulations under the proposed method. Table 5 presents the EEG for a day, month, and year. 
TABLE 3: Results of three first steps in Merida city.

\begin{tabular}{lcccccccccc}
\hline Manufac. & NOCT & $R_{p}$ & $R_{s}$ & $V_{\text {mpp }}$ & $I_{\text {mpp }}$ & $V_{\text {oc }}$ & $I_{\text {sc }}$ & $K_{i}$ & $K_{v}$ \\
\hline Jinshi & 47 & 381.5 & 0.38 & 29.95 & 8.35 & 37.66 & 8.92 & 0.0051 & -0.124 & 60 \\
Solartec & 45 & 400.7 & 0.37 & 30.12 & 8.31 & 37.85 & 8.65 & 0.0053 & -0.123 & 60 \\
LDK & 45 & 550.1 & 0.4 & 29.9 & 8.38 & 37.8 & 8.92 & 0.0053 & -0.118 & 60 \\
Candian & 45 & 341.2 & 0.31 & 30.11 & 8.31 & 37.42 & 8.83 & 0.0035 & -0.112 & 60 \\
Kewell & 47 & 156.5 & 0.25 & 30.72 & 7.99 & 37.55 & 8.68 & 0.0017 & -0.127 & 60 \\
\hline
\end{tabular}

TABle 4: Py and $\eta$ for 5 PV panels at Merida city.

\begin{tabular}{lccccccc}
\hline Manufac. & MMPP $(\mathrm{W})$ & $P_{\mathrm{mpp}(\mathrm{STC})}(\mathrm{W})$ & Area $\left(\mathrm{m}^{2}\right)$ & $\mathrm{Py}_{(\text {local })}\left(\mathrm{W} / \mathrm{m}^{2}\right)$ & $\mathrm{Py}_{\text {STC }}\left(\mathrm{W} / \mathrm{m}^{2}\right)$ & $\eta_{(\mathrm{STC})}{ }^{*}(\%)$ & $\eta_{\text {Real }}{ }^{* *}(\%)$ \\
\hline Jinshi & 99.5 & 250 & 1.63 & 61.04 & 153.37 & 15.34 \\
Solartec & 101.5 & 250 & 1.62 & 62.65 & 154.32 & 15.43 \\
LDK & 100.8 & 250 & 1.63 & 61.84 & 153.37 & 15.34 \\
Canadian & 86.72 & 250 & 1.63 & 53.20 & 153.37 & 15.34 \\
Kewell & 92.55 & 250 & 1.62 & 57.13 & 154.32 & 14.52 \\
\hline
\end{tabular}

${ }^{*} E_{\mathrm{STC}}=1000 \mathrm{~W} / \mathrm{m}^{2} ;{ }^{* *} E_{\text {mean }}=425.78 \mathrm{~W} / \mathrm{m}^{2}$.

TABLE 5: EEG at Merida per day, month, and year.

\begin{tabular}{lccccc}
\hline Manufact. & $\mathrm{Py}_{(\text {local })}\left(\mathrm{W} / \mathrm{m}^{2}\right)$ & $\mathrm{Hr}_{\text {day }}(\mathrm{hr})$ & $\mathrm{EEG}_{(\text {day })}\left(\mathrm{kWhr} / \mathrm{m}^{2}\right)$ & $\mathrm{EEG}_{(\mathrm{month})}\left(\mathrm{kWhr} / \mathrm{m}^{2}\right)$ & $\mathrm{EEG}_{(\mathrm{annual})}\left(\mathrm{kWhr} / \mathrm{m}^{2}\right)$ \\
\hline Jinshi & 99.5 & 12.17 & 1.21 & 36.93 & 34.19 \\
Solartec & 101.5 & 12.17 & 1.24 & 37.42 & 452.10 \\
LDK & 100.8 & 12.17 & 1.23 & 32.19 & 448.99 \\
Canadian & 86.72 & 12.17 & 1.06 & 34.35 & 386.27 \\
Kewell & 92.55 & 12.17 & 1.13 & & 412.24 \\
\hline
\end{tabular}

TABLE 6: Investment and total area required for JAPAY project at Merida.

\begin{tabular}{|c|c|c|c|c|c|}
\hline Manufact. & $\mathrm{EEG}_{(\text {day })}\left(\mathrm{kWhr} / \mathrm{m}^{2}\right)$ & Cost (\$USD) & ${ }^{*}$ Panels (\#) & Investment (\$USD) & Tot. area $\left(\mathrm{m}^{2}\right)$ \\
\hline Jinshi & 1.21 & 337.5 & 490 & $\$ 165,375$ & 798.70 \\
\hline Solartec & 1.24 & 329.8 & 480 & $\$ 158,304$ & 777.60 \\
\hline LDK & 1.23 & 347.2 & 483 & $\$ 167,698$ & 787.29 \\
\hline Candian & 1.06 & 335.4 & 562 & $\$ 188,495$ & 916.06 \\
\hline Kewell & 1.13 & 347.1 & 526 & $\$ 182,575$ & 852.12 \\
\hline
\end{tabular}

${ }^{*}$ To generate $95 \%$ of $623.6 \mathrm{kWhr} /$ day.

According to the simulation results of the method, the Solartec S60MC250 PV panel had the best yield and electrical energy production. However, for the JAPAY project, now it is important to know the PV panel investment and the area required for the project.

Therefore it is necessary to determine the number of PV panels needed for installation in order to cover the $95 \%$ of Sewage Treatment Plant consumption. Starting with the consumption annual daily mean $\left(C_{\text {mean }}\right)$ from Federal Commission of Electricity (CFE) billings, $C_{\text {mean }}=623.6 \mathrm{kWhr}$ :

$$
N_{\text {panel }}=\frac{C_{\text {mean }} * 0.95}{\mathrm{EEG}_{(\text {day })}} \text {, }
$$

Tot. Area $=N_{\text {panel }} *$ Area $_{\mathrm{PV}}$.
Table 6 shows the application of (11) for the same five PV panels to obtain the investment and total area required.

The proposed method was the base of the study developed for the JAPAY project, which was implemented successfully, which ensured the projected electric power generation and ensured the planned investment. Figure 13 shows the photovoltaics facilities.

Nowadays the Sewage Treatment Plant produces its own electric energy, and it is an example of photovoltaics project for Merida city. Figure 14 demonstrates the power generated by PV panels that reaches $48 \mathrm{kWp}$ and it is close to the power calculated by the proposed method. Figure 15 shows how the power delivered by electric energy supply company (CFE) was the supplement of total electric power demanded by Sewage Treatment Plant (Figure 16). 

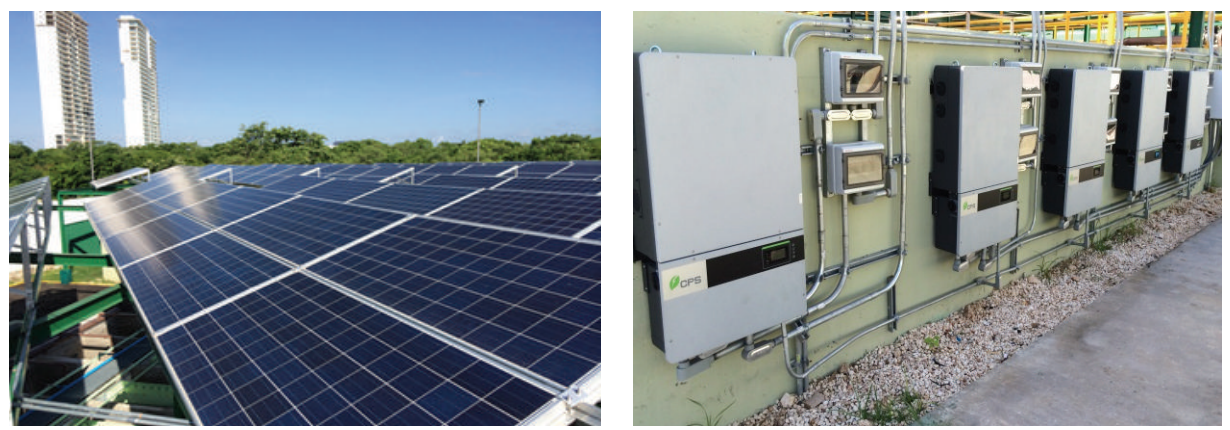

FIgURE 13: PV facilities of JAPAY in Merida city.

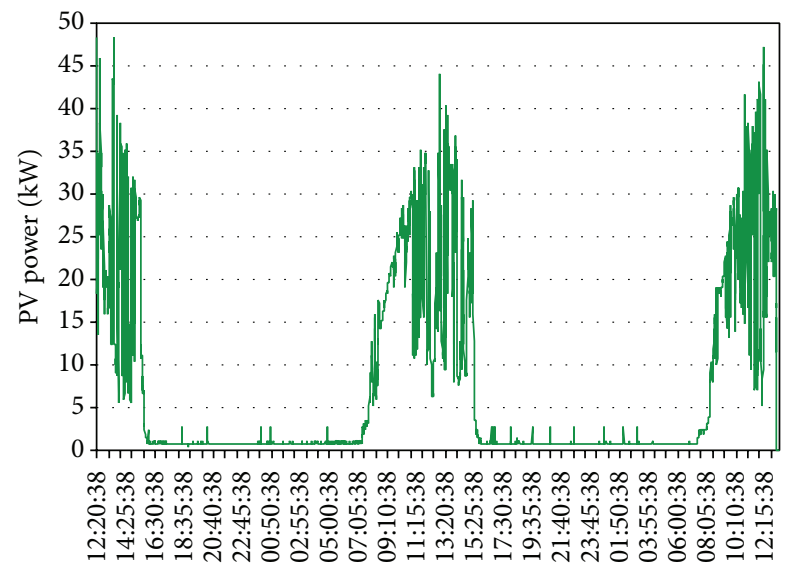

FIGURE 14: Photovoltaic power generated.

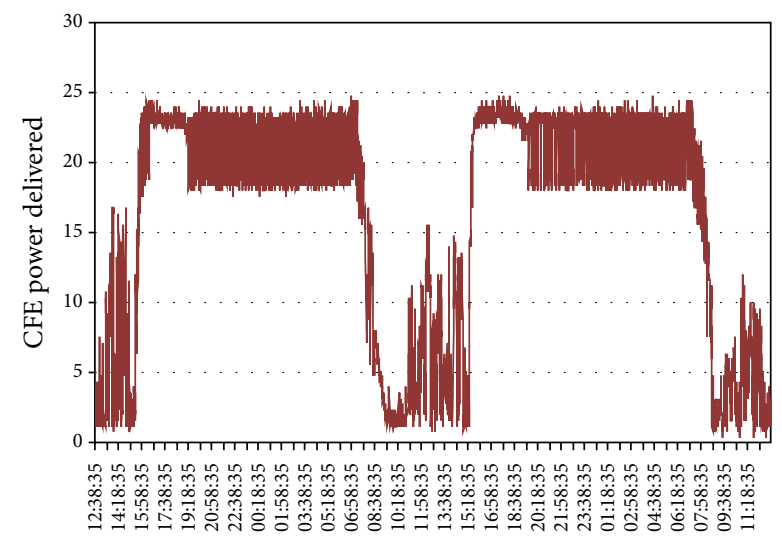

FIGURE 15: CFE power delivered.

\section{Conclusions}

In this paper a practical five-step method is presented to estimate the electrical energy generated by PV panel per day, month, and year, based on the MATLAB Simulink mathematical model of the PV cell and the evaluation of historic climatic variables for a specific locality.

Most of the literature works only estimate the energy potential by geographic information systems (GIS) and PVGIS,

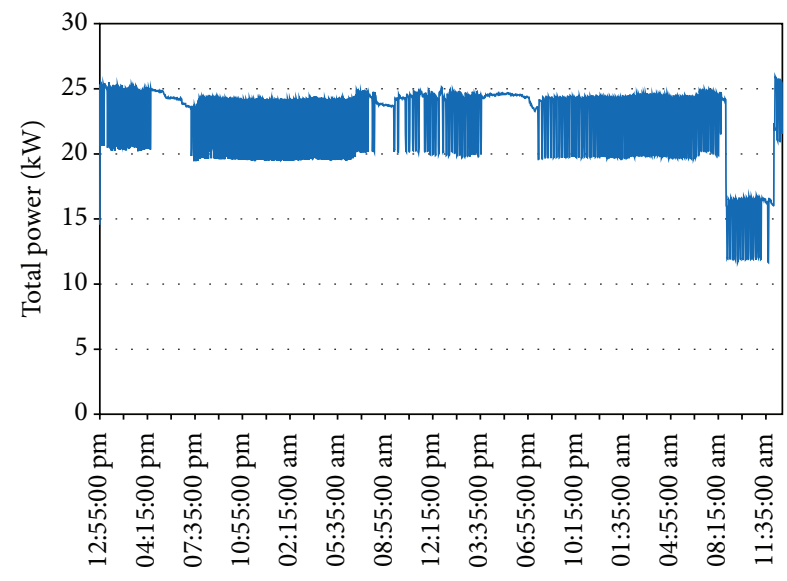

Figure 16: Power demand by Sewage Treatment Plant.

maps of solar radiation $\left(\mathrm{W} / \mathrm{m}^{2}\right)$, digital surface models (DSM), and simulations of climate variables, but any reported method calculates the energy generated and considers any simultaneity to the response due to intrinsic characteristic between different PV panels and the historical climatic database, so the proposed method incorporates these conditions allowing for a more realistic calculation.

It has been demonstrated that there are significant differences in electric energy generation and power yield and its efficiency between the five different PV panels under test. These differences are always lower than STC and therefore are important and critical to estimate the number of panels, the facilities total area, and the PV panels investment required on a project.

The proposed method developed represents a powerful software tool for calculating the electric energy generated by a PV panel. The proposed method provides a good reliability and certainty for PV project investment and allows application in different geographical locations, different PV power peaks, and different panels manufacturers.

\section{Conflict of Interests}

The authors declare that there is no conflict of interests regarding the publication of this paper. 


\section{Acknowledgments}

The authors thank CONAGUA Mérida for the assistance provided with the database. Likewise, the authors would like to express their gratitude to Dr. David Valdes Lozano, CINVESTAV, Mérida, for providing weather database. Finally, the authors acknowledge researchers and reviewers of Scientific Research Center of Yucatan A.C. (CICY).

\section{References}

[1] International Energy Agency (IEA), World Energy Outlook 2013, International Energy Agency (IEA), Paris, France, 2013.

[2] Renewable Energy Policy Network for the 21st Century (REN21), "Renewable 2012," Global Status Report, Renewable Energy Policy Network for the 21st Century (REN21), Paris, France, 2012.

[3] B. Parida, S. Iniyan, and R. Goic, "A review of solar photovoltaic technologies," Renewable and Sustainable Energy Reviews, vol. 15, no. 3, pp. 1625-1636, 2011.

[4] B. van der Zwaan and A. Rabl, "The learning potential of photovoltaics: implications for energy policy," Energy Policy, vol. 32, no. 13, pp. 1545-1554, 2004.

[5] H. C. Hottel, "A simple model for estimating the transmittance of direct solar radiation through clear atmospheres," Solar Energy, vol. 18, no. 2, pp. 129-134, 1976.

[6] B. Y. H. Liu and R. C. Jordan, "The interrelationship and characteristic distribution of direct, diffuse and total solar radiation," Solar Energy, vol. 4, no. 3, pp. 1-19, 1960.

[7] I. R. Pillai and R. Banerjee, "Renewable energy in India: status and potential," Energy, vol. 34, no. 8, pp. 970-980, 2009.

[8] S. N. Benger, S. Zhou, and H. Guan, "A dynamic solar irradiance model for assessing solar PV power generation potential in urban areas," in Proceedings of the International Conference and Utility Exhibition on Green Energy for Sustainable Development (ICUE '14), pp. 1-4, March 2014.

[9] K. Shukla, S. Rangnekar, and K. Sudhakar, "Mathematical modelling of solar radiation incident on tilted surface for photovoltaic application at Bhopal, M.P., India," International Journal of Ambient Energy, 2015.

[10] M. D. Siegel, S. A. Klein, and W. A. Beckman, "A simplified method for estimating the monthly-average performance of photovoltaic systems," Solar Energy, vol. 26, no. 5, pp. 413-418, 1981.

[11] J. Hofierka and J. Kaňuk, "Assessment of photovoltaic potential in urban areas using open-source solar radiation tools," Renewable Energy, vol. 34, no. 10, pp. 2206-2214, 2009.

[12] M. R. Hossain, A. M. T. Oo, and A. B. M. S. Ali, "The effectiveness of feature selection method in solar power prediction," Journal of Renewable Energy, vol. 2013, Article ID 952613, 9 pages, 2013.

[13] A. F. A. Kadir, T. Khatib, and W. Elmenreich, "Integrating photovoltaic systems in power system: power quality impacts and optimal planning challenges," International Journal of Photoenergy, vol. 2014, Article ID 321826, 7 pages, 2014.

[14] M. Súri, T. A. Huld, E. D. Dunlop, and H. A. Ossenbrink, "Potential of solar electricity generation in the European Union member states and candidate countries," Solar Energy, vol. 81, no. 10, pp. 1295-1305, 2007.
[15] R. Ayaz, I. Nakir, and M. Tanrioven, "An improved MatlabSimulink model of PV module considering ambient conditions," International Journal of Photoenergy, vol. 2014, Article ID 315893, 6 pages, 2014.

[16] K. J. Sauer, T. Roessler, and C. W. Hansen, "Modeling the irradiance and temperature dependence of photovoltaic modules in PVsyst," IEEE Journal of Photovoltaics, vol. 5, no. 1, pp. 152-158, 2015.

[17] M. E. Meral and F. Diner, "A review of the factors affecting operation and efficiency of photovoltaic based electricity generation systems," Renewable and Sustainable Energy Reviews, vol. 15, no. 5, pp. 2176-2184, 2011.

[18] K. Nishioka, T. Hatayama, Y. Uraoka, T. Fuyuki, R. Hagihara, and M. Watanabe, "Field-test analysis of PV system output characteristics focusing on module temperature," Solar Energy Materials and Solar Cells, vol. 75, no. 3-4, pp. 665-671, 2003.

[19] Atmospheric Sciencie Data Center (ASDC), National Aeronautics and Space Administration (NASA), Langley Reserch Center, https://eosweb.larc.nasa.gov/.

[20] ESRA (European Solar Radiation Atlas) - HelioClim Solar Radiation, http://www.helioclim.org/esra/.

[21] Comisión Nacional del Agua, CONAGUA, http://www.cna.gob $. \mathrm{mx} /$.

[22] Weather Link Station and Centro de Investigacion Cientifica y Avanzada, CINVESTAV, http://www.mda.cinvestav.mx/ weather.

[23] Solartec, Photovoltaic Multicrystaline Module 250 Watt, Model S60MC, http://www.solartec.mx/productos.html.

[24] Y. T. Tan, D. S. Kirschen, and N. Jenkins, "A model of PV generation suitable for stability analysis," IEEE Transactions on Energy Conversion, vol. 19, no. 4, pp. 748-755, 2004.

[25] A. Kajihara and A. T. Harakawa, "Model of photovoltaic cell circuits under partial shading," in Proceedings of the IEEE International Conference on Industrial Technology (ICIT'05), pp. 866-870, IEEE, Hong Kong, December 2005.

[26] E. Matagne, R. Chenni, and R. El Bachtm, "A photovoltaic cell model based on nominal data only," in Proceedings of the International Conference on Power Engineering, Energy and Electrical Drives (POWERENG '07), pp. 562-565, Setubal, Portugal, April 2007.

[27] R. Chenni, M. Makhlouf, T. Kerbache, and A. Bouzid, "A detailed modeling method for photovoltaic cells," Energy, vol. 32, no. 9, pp. 1724-1730, 2007.

[28] M. G. Villalva, J. R. Gazoli, and E. R. Filho, "Comprehensive approach to modeling and simulation of photovoltaic arrays," IEEE Transactions on Power Electronics, vol. 24, no. 5, pp. 11981208, 2009.

[29] D. Sera, R. Teodorescu, and P. Rodriguez, "PV panel model based on datasheet values," in Proceedings of the IEEE International Symposium on Industrial Electronics (ISIE '07), pp. 23922396, Vigo, Spain, June 2007.

[30] K. Ishaque, Z. Salam, H. Taheri, and Syafaruddin, "Modeling and simulation of photovoltaic (PV) system during partial shading based on a two-diode model," Simulation Modelling Practice and Theory, vol. 19, no. 7, pp. 1613-1626, 2011.

[31] S. Shongwe and M. Hanif, "Comparative analysis of different single-diode PV modeling methods," IEEE Journal of Photovoltaics, vol. 5, no. 3, pp. 938-946, 2015.

[32] W. Xiao, F. F. Edwin, G. Spagnuolo, and J. Jatskevich, "Efficient approaches for modeling and simulating photovoltaic power systems," IEEE Journal of Photovoltaics, vol. 3, no. 1, pp. 500508, 2013. 
[33] K. Ishaque and Z. Salam, "An improved modeling method to determine the model parameters of photovoltaic (PV) modules using differential evolution (DE)," Solar Energy, vol. 85, no. 9, pp. 2349-2359, 2011.

[34] A. Márquez, E. Gómez, D. Aranda, and M. Bohorquez, "Sistema para la generación automática de curvas V-I, V-P y monitorización de módulos fotovoltaicos," in XXV Jornadas Automática, Ciudad Real, Spain, September 2004.

[35] F. Lasnier and T. Gang-Ang, Photovoltaic Engineering Handbook, Adam Hilger, Bristol, UK, 1990.

[36] D. L. King, J. A. Kratochvil, and W. E. Boyson, “Temperature coefficients for PV modules and arrays: measurement methods, difficulties, and results," in Proceedings of the IEEE 26th Photovoltaic Specialists Conference, pp. 1183-1186, October 1997.

[37] M. C. A. García and J. L. Balenzategui, "Estimation of photovoltaic module yearly temperature and performance based on Nominal Operation Cell Temperature calculations," Renewable Energy, vol. 29, no. 12, pp. 1997-2010, 2004. 

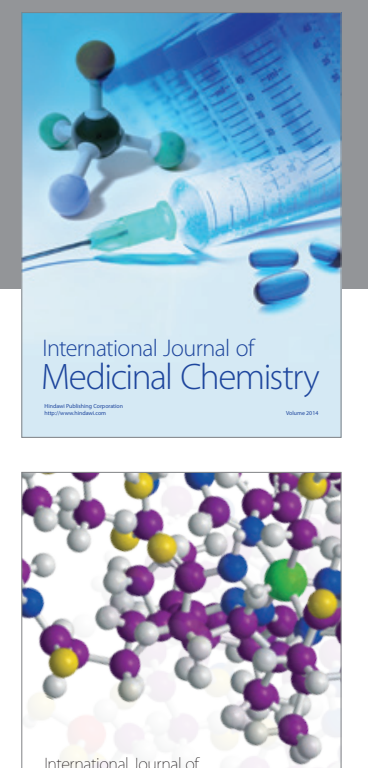

\section{Carbohydrate} Chemistry

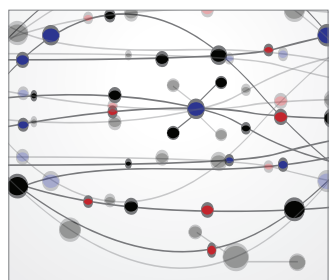

The Scientific World Journal
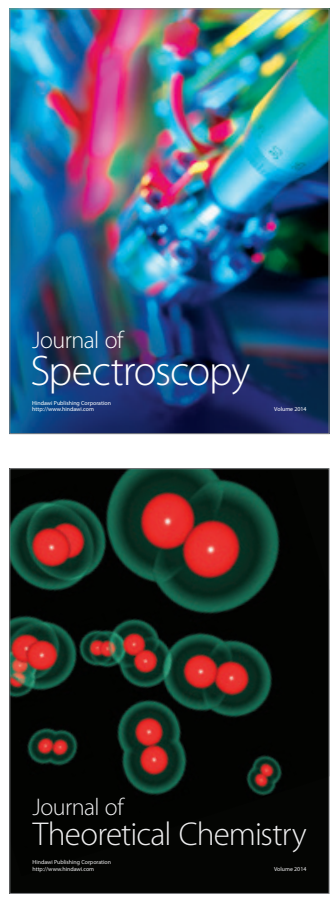
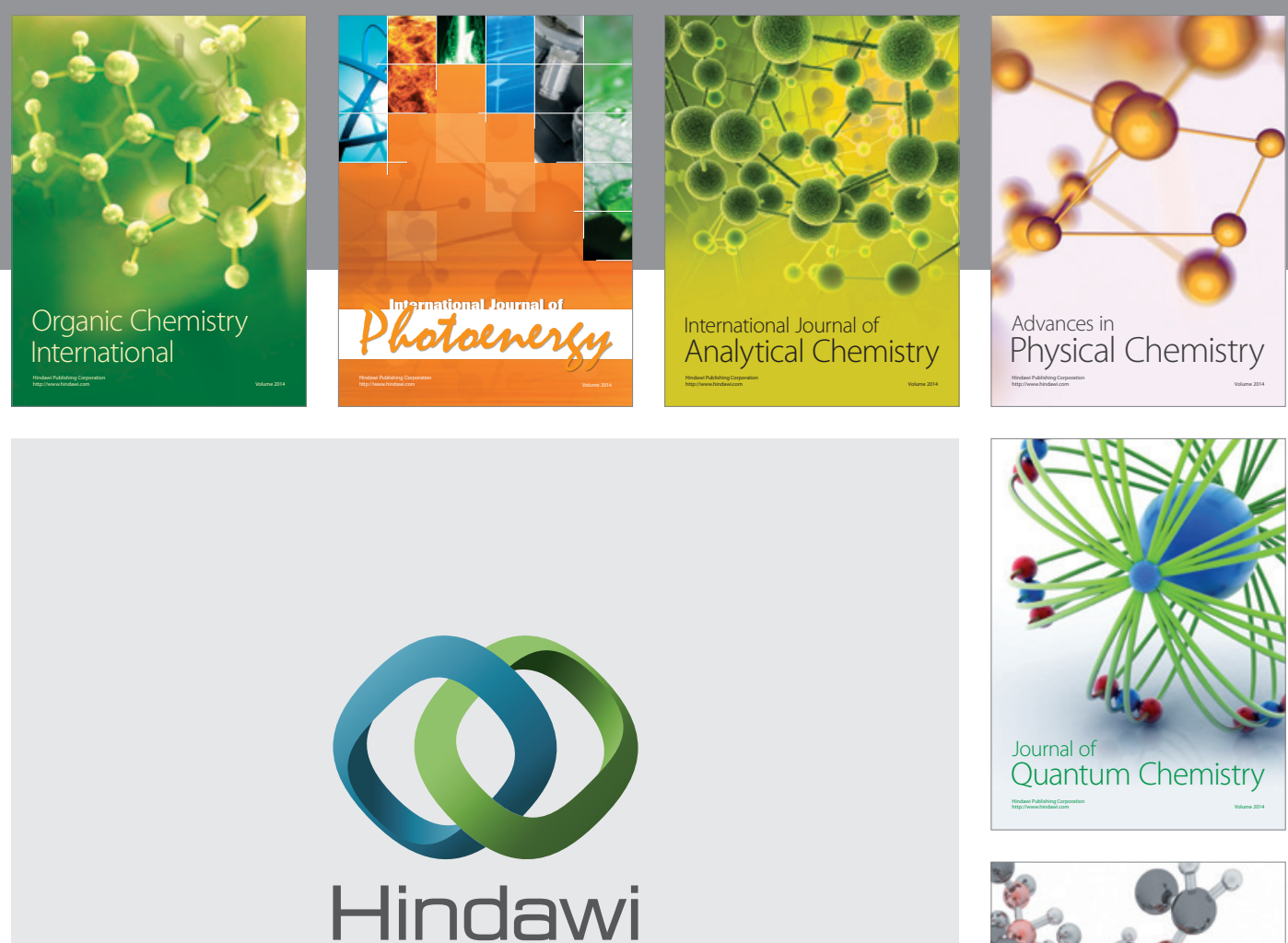

Submit your manuscripts at

http://www.hindawi.com

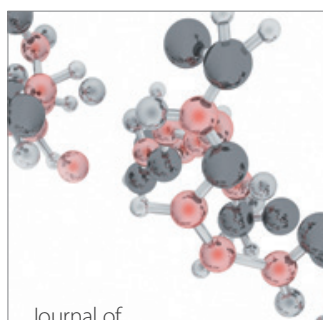

Analytical Methods

in Chemistry

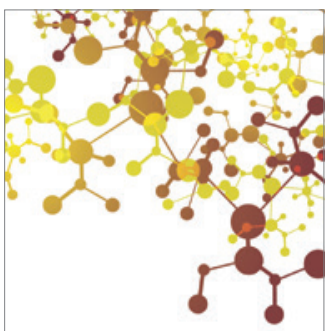

Journal of

Applied Chemistry

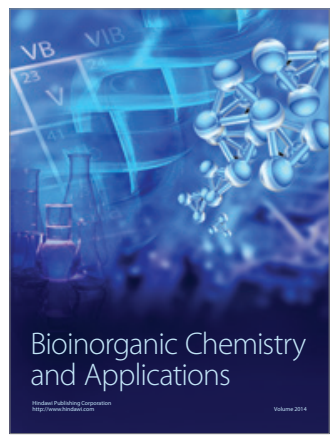

Inorganic Chemistry
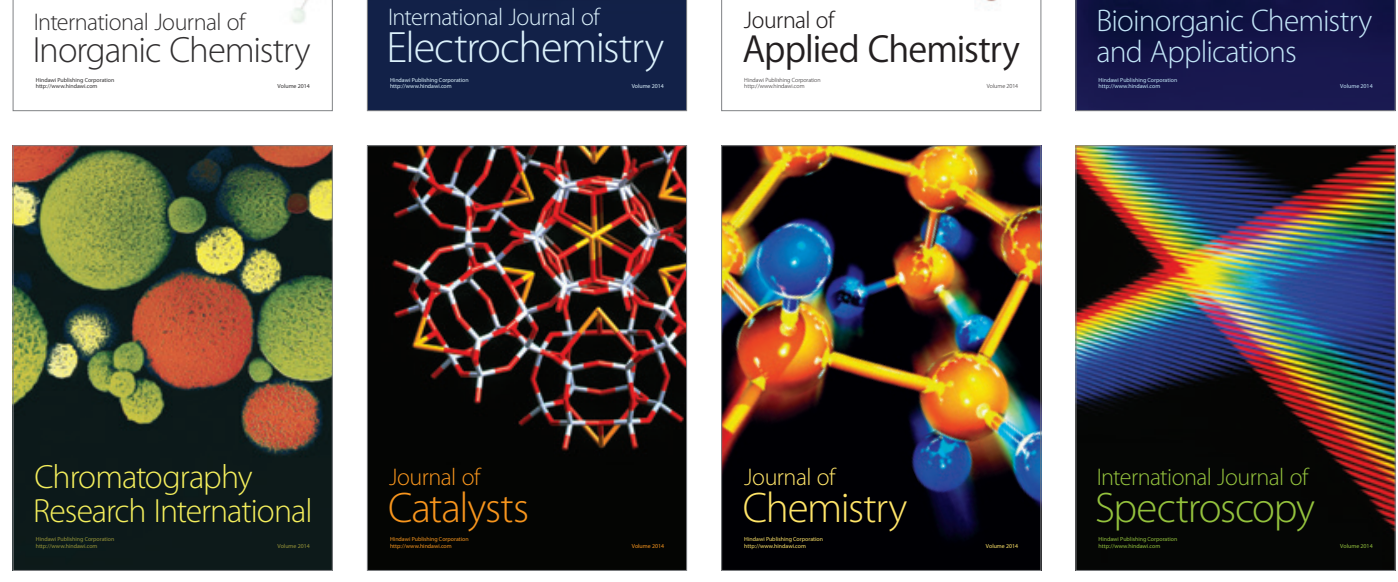